\title{
Parents on the front lines of COVID-19 face tough choices
}

\author{
— Cite as: CMAJ 2020 April 27;192:E467-8. doi: 10.1503/cmaj.1095864
}

Posted on cmajnews.com on April 10, 2020

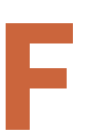
ront-line health care workers with children are grappling with difficult decisions about how to protect their families as Canada's coronavirus disease 2019 (COVID-19) outbreak worsens. Many were already managing a precarious work-life balance and complex child care arrangements before the pandemic. But COVID-19 has brought new challenges and anxieties.

"The hardest thing is that you can bring this disease home," says Dr. David Carr, a Toronto emergency physician with three children. Exposure to infectious disease is an occupational hazard to which Carr is accustomed, but COVID-19 is hitting home differently. For the first time in his career, Carr says, he feels scared going to work.

Because his spouse is also a hospitalbased physician, isolating from the children is logistically difficult. And their most dependable source of child care is off limits. "We can't expose the grandparents to this virus," Carr says. "Should the kids go somewhere else? How can we not see them for the next four months?"

For now, Carr and his spouse are alternating schedules and managing without additional supports. However, that approach only works so long as they are healthy.

Health care workers account for as many as 1 in 10 cases of COVID-19 in some provinces. Even more troubling, supplies of protective equipment are running low across the country.

"I am walking into this pandemic having no expectation that I have any protection," says Dr. Samina Ali, an Edmontonbased pediatric emergency physician who is married to an emergency physician and has three teenage children. Ali's husband also has preexisting conditions that may make him more vulnerable to COVID-19. "The elephant in the room is what happens if one of us becomes critically ill," she says.

In Singapore and the United Kingdom, some health care providers are staying in hotels for weeks to avoid spreading the virus to their families. Ali isn't sure if she could do the same. "The only reason I am uneasy about sending their children into group settings.

"I don't know if the right solution is to cohort front-line workers' kids in a school setting," says Dr. Robert Ohle, an emergency physician in Sudbury who has two young children. "The kids are vectors of disease, with a constant stream of upper respiratory tract infections from daycare,

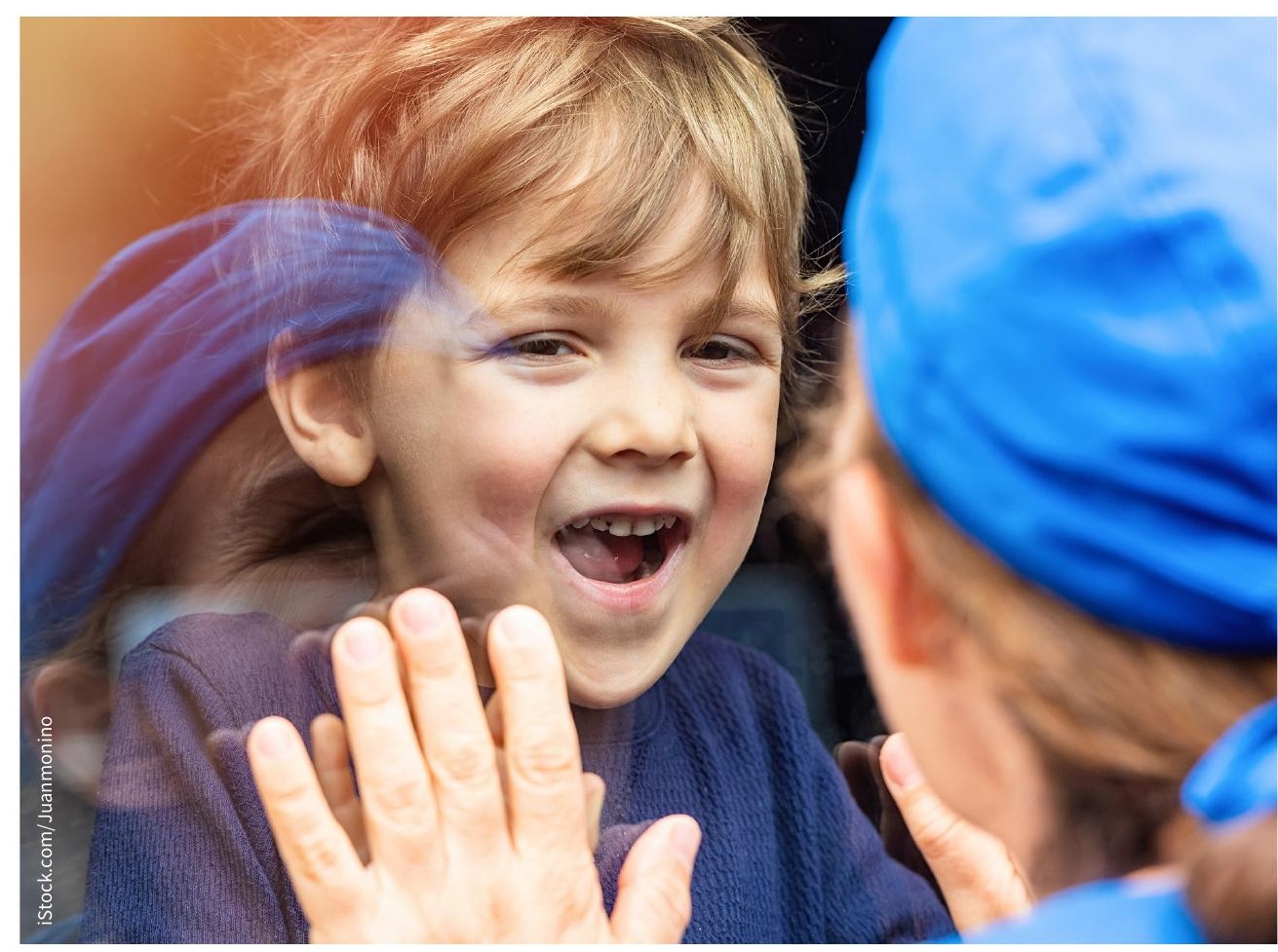

COVID-19 has created new challenges and anxieties for health care workers who are parents.

getting through this is seeing my children's faces every day."

Provinces are ramping up child care supports for front-line workers with young children. In Ontario, the provincial government is reopening emergency child care centres for essential workers. However, some health professionals are whether COVID-19 or something else." Even a mild infection can be a major hassle at a time when health systems need all hands on deck. Parents who get sick from their kids are "knocked out" for the time it takes to rule out COVID-19, Ohle says.

In Ontario, public health officials have advised emergency child care centres to 
ask parents to check their children's temperatures daily and keep those with fever or cold-like symptoms at home.

Ohle and his wife, an anesthesiologist and intensivist, have been able to adjust their shifts so that one of them is always at home with their children. Ohle says it's not ideal, but it feels like the safest option for his family.

"We are all looking for ways to regain the narrative of control in our lives right now," Ohle says.

Ohle, Carr and Ali all perform careful decontamination rituals when they arrive home from the hospital. Carr's family has a designated "hot zone," which they treat as if it harbours the virus and only use when entering or exiting their home. Ali methodically washes her hands and showers before allowing her children near her. And Ohle jokes about "getting naked at my front door for all of the neighbours to see."

These rituals provide a "sense of control," although the future remains uncertain, Ohle says. He and his wife are preparing for the worst. "We have definitely had the morbid conversations to make sure our wills are up to date, making sure our friends and family know the guardians for the kids, and what we are doing for financial support if we both become critically ill."

The Ontario Medical Association emailed members in March with tips and resources for updating wills or writing a first will. The association said it compiled the resources in response to requests from members.

For Ali, planning for the worst brings peace of mind. "At that point, you can't do any more."

Dr. Catherine Varner, Toronto, Ont. 